This is an Accepted Manuscript of an article published by Taylor \& Francis in the Journal of Intervention and Statebuidling on 22 July 2016, available at:

http://www.tandfonline.com/doi/full/10.1080/17502977.2016.1208992

\title{
Deconstructing Dayton: Ethnic politics and the legacy of war in Bosnia and Herzegovina
}

\section{Patrick Pinkerton}

\begin{abstract}
Twenty years after the signing of the Dayton Peace Agreement (DPA) which brought the conflict in Bosnia and Herzegovina $(\mathrm{BiH})$ to an end, the dysfunctional nature of the Bosnian state means that the question of how political actors in BiH engage with the DPA as a response to the war remains vitally important. This article argues that moving beyond the ethnicisation of politics in $\mathrm{BiH}$ enacted by the DPA can be achieved by challenging the understandings of the war which informs the DPA while simultaneously challenging the effects of these understandings in the present. By advancing what I term a 'deconstructive conclusion' of the DPA, this article demonstrates the practical utility of Jacques Derrida's thought for engaging with the legacy of war in BiH.
\end{abstract}

Keywords: Derrida; supplement; Dayton Peace Accords; Balkans; February 2014 protests.

Word Count: 8, 351

\section{Introduction}

The twentieth anniversary in late 2015 of the signing of the Dayton Peace Accords (DPA), which brought the devastating war in Bosnia and Herzegovina $(\mathrm{BiH})$ to an end, was the occasion for numerous high-profile commemorative and reflective events, in $\mathrm{BiH}$, Dayton, Ohio and elsewhere. The anniversary of the DPA, which was negotiated between Slobodan Milošević, Alija Izetbegović and Franjo Tuđman, the Presidents of Federal Republic of Yugoslavia, BiH and Croatia respectively, and delegates from the USA, UK, France, Germany, Russia and the EU, also prompted calls from analysts to revisit the DPA in the search for solutions to contemporary conflicts such as the ongoing war in Syria (Stavridis, 2015). Yet as the current High Representative for BiH Valentin Inzko (2015) noted in a statement marking the anniversary, disagreements amongst politicians in BiH over the division of competencies as set-out in the DPA has replaced a sustained concern with the economic and social issues affecting the post-war country. This mismanagement has resulted in an unemployment rate which has hovered around the $40 \%$ mark for the last decade (Efendić and Hadžiahmetović 2015, 119), and allowed Florian Bieber to write of an academic consensus that BiH 'is stuck in a steady, yet not stable, degrading deadlock' (Bieber 2015a, 215). The question of how political actors in BiH engage with the DPA as a response and solution to the catastrophic war therefore remains vitally important, both for $\mathrm{BiH}$ and the wider politics of conflict resolution. 
The impact that the DPA has had on BiH has long been an object of critical scholarship (Campbell 1998; Chandler 2000; Bose 2002), and a substantial body of literature now exists addressing the issues of how the DPA, while preventing a return to open conflict in $\mathrm{BiH}$, has failed to deliver economic development, political reconciliation and effective state institutions. Some recent suggestions for how the DPA could be reformed to allow for more positive outcomes for Bosnians include moving from a territorially- and ethnically-based consociational system to a language-based one (Stroschein 2014), holding transparent and inclusive reform talks that are not constrained by rigid schedules and rushed deadlines (Sebastián 2012), and using organisational (Howard 2012) or external (McEvoy 2014) incentives to promote peacebuilding and cross-ethnic reconciliation within the context of the DPA.

The present article will add to this literature, but rather than putting forward new suggestions for reform of the DPA, I will enact a deconstruction of the ethnic logics embedded within the DPA. The central claim of the article is that moving beyond the divisive and dysfunctional ethno-nationalist ${ }^{1}$ posturing that characterises contemporary politics in $\mathrm{BiH}$ can be achieved though challenging the ethnic understandings of the war which inform the DPA while simultaneously challenging the effects of these understandings in the present. The article will illustrate how a particular understanding of the ethnic drivers of the conflict was written-in to the DPA and transmitted into the political present of $\mathrm{BiH}$. Reconstructing how the DPA fixes the myriad framings of the war deployed through the international engagements during the conflict into a singular conceptualisation in turn opens the possibility for a deconstruction of the DPA, which I argue is necessary to allow politics in BiH to develop outside the debilitating ethnic constraints that the DPA has placed upon it.

The article will proceed across four sections. In the first I focus on two contradictory framings of the conflict employed by international actors that informed major components of the DPA: the understanding of the conflict as driven by ethnic identity; and that which apportioned blame on the nationalist policies of Milošević and Tuđman. This will lay the groundwork for the second section, which argues that these contradictory understandings are held together in the DPA through reference to an understanding of the Balkans as a region of historic ethnic enmity. The article will engage here with Jacques Derrida's notions of undecidability and the supplement to argue that a 'Balkans' war understanding continues to operate as a necessary reference point for the institutional- and territorial-divisions of $\mathrm{BiH}$ enacted by the DPA. The third section advances a deconstructive reading of the DPA and the 'Balkans' war discourse contained within it, indicating how this could be put into practice through an engagement with the protest movements which have developed in BiH from 2012. The final section advances what I call, in an addition to the Derridean lexicon, a 'deconstructive conclusion' which, I argue, can be utilised to simultaneously challenge the fixed understanding of the war which informs the DPA and the ethnically- and territorially-divided political structures that document produced. In doing so, I will also illustrate the practical utility of Derridean thought for engaging with conflict and post-conflict situations.

\section{Ethnicity, war and the international engagements with BiH}

There is no simple way to summarise the myriad international responses to the 1992-95 Bosnian war. As Toal and Dahlman $(2011,146)$ have stated:

Many and multiple types of actors were involved: major powers, international organizations, media networks, support coalition activists, and diasporic 
organizations. Major powers were at odds and often internally divided as well, with diplomatic and military institutions advocating different responses. Fundamental disagreements about the nature of the war frequently produced policies and implementation strategies that were incoherent and dysfunctional.

I lack the space to reconstruct the full complexities of these international engagements, so I will instead focus attention on two framings of the conflict prevalent in the international imaginary: that which saw it as an irresolvable civil war caused by the clash of competing ethnic identities; and the concurrent view that the Bosnian war was an international conflict caused by the expansionist policies of Milošević and Tuđman.

These framings have been chosen for two reasons. Firstly, while they were not the only lenses through which the conflict was conceptualised, they were prominent ones whose impacts can be traced through the war-time engagements to the Dayton process and into the contemporary political environment of $\mathrm{BiH}$. Secondly, they are contradictory, offering incompatible accounts of the factors driving the conflict. Taken in tandem with my first reason for examining these framings, this factor focuses our attention on the need to understand how two opposing accounts were reconciled in the DPA and the institutions it created. As I will illustrate, in order to reduce the conflict to a problem that could be solved through a peace process, the contradictory framings were merged into a singular conceptualisation. This movement of structuring the experience of the war into a meaningful whole is what allowed for the negotiation, signing and (partial) enforcement of the DPA. By the same token, however, the fact that such a structuring of divergent threads into a coherent whole has taken place is what allows for a deconstruction to be undertaken. I will now summarise these framings in turn, before tracing their effects through the DPA. In doing so, I will follow V. P. Gagnon (2004, xv) and his characterisation of ethnicity in the former Yugoslavia as something that many people did identify with, but in a way that 'was not homogenous nor... unchanging'. The DPA will therefore not be criticised for creating ethnic identities that had no prior existence but, rather, for producing a fixed conception of ethnic identity through the political structures it created. What this article will contribute to understandings of ethnicity in $\mathrm{BiH}$ is an appreciation of how it has been temporally fixed through the DPA and, subsequently, how this can be challenged through a deconstructive conclusion which unsettles the fixed historical narratives of the conflict which continue to structure politics in $\mathrm{BiH}$.

\section{Framing the role of ethnicity in the Bosnian war}

One understanding employed by international actors engaging with the Bosnian war saw it as a conflict between three divergent and opposed ethnic groups. This 'ethnic war' account was rooted in a 'primordialist' conception of ethnic identity, in which ethnicity is seen as existing prior to social relations, and thus capable of determining behaviour through the strong emotional bonds it places on ethnic subjects (Eller and Coughlan 1993). David Campbell (1998) has highlighted the centrality of territory to this conceptualisation, showing how, from the very beginning of the international engagements with the former Yugoslavia, the war in BiH was conceived by international mediators as being fought between three homogenous ethnic groups competing for an ethnically-homogenous territory. Campbell (128) notes how in March 1992, before war had even reached BiH, a meeting of the European Community Working Group proposed a BiH divided into three constituent parts, one for each of the sovereign 'Muslim, Serb and Croat nations', as the only peaceful way forward. 
Campbell $(130,157)$ also details how the subsequent attempts at fostering peace contributed to the 'ethnicization of Bosnia by the international community, in tandem with the parties to the conflict', until BiH was enshrined 'as a place where political identity is fixed in terms of ethnic exclusivity'.

A competing understanding of the war, which ran concurrently to that discussed above, saw the conflict as caused by Serb and Croat aggression, inspired by the violent and conservative nationalism of Milošević and Tuđman, and mainly directed against innocent Bosnian Muslims. This discourse chimes with a constructivist conceptualisation of ethnic conflict, whereby instrumental elites are seen to mobilise differences along previously-existing ethnic cleavages in order to achieve specific political goals (Gagnon Jr. 1994/95). Contra the primordialist account, constructivists see group consciousness as driven by 'ethnic entrepreneurs', rather than being the products of innate forces residing within fixed ethnic identities. This understanding allowed the conflict to be viewed through a 'humanitarian' frame (Toal and Dahlman 2011, 145), justifying the extensive aid and assistance missions that operated in $\mathrm{BiH}$ throughout the war and, with the violence against Sarajevo and the eastern enclaves worsening, the two-week NATO air campaign in the summer of 1995 directed against Serb military positions (Silber and Little 1996, 366). It also provided the impetus for international actors to seek a political solution to the violence that could maintain BiH's sovereign integrity, as those possessing this view were more likely to see ethnic resentment as a consequence of the hardening of ethnic identities through extreme violence (Kaufmann 1996), not the cause of hostilities as the primordialist account would maintain.

While the primordial-inspired account initially held sway amongst the Clinton administration (infamously inspired by Robert Kalpan's Balkan Ghosts), as the war progressed the role of instrumental elites in driving the conflict began to take precedence in outside analyses (Howard $2015,7)$. However, the fact that major international figures had at times expressed a view of the conflict as ethnically-driven gave succour to the objectives of the extreme nationalists involved in the fighting. When it came to negotiating an end to the war, therefore, the presence of representatives of the warring parties around the table ensured that the ethnic understanding of the conflict found its way into the DPA (Toal and Dahlman 2011, 164).

The consequences of the 'ethnic war' framing can be traced to Annex 4 of the DPA, which details the constitution of $\mathrm{BiH}$. This document produced a consociational political system characterised by a series of territorial and institutional divisions along ethnic lines (Cooley 2013, 178-179), the most striking being the separation of $\mathrm{BiH}$ into two entities, the Federation of $\mathrm{BiH}(\mathrm{FBiH})$ and Republika Srpska (RS). These entities are vested with a wide range of competencies, making $\mathrm{BiH}$ a highly decentralised state. The constitution also divides the upper house of the state-level Parliamentary Assembly, the House of Peoples, and the tripartite state Presidency, into Bosnian Muslim (or 'Bosniak'), Croat and Serb delegations. The representatives of each ethnic group, both in the Parliament and the Presidency, are also provided with the power to declare a decision to be 'destructive of the vital interest' of their group (Kappler 2013, 14). The insertion of these de facto ethnic veto points into the Bosnian political system (Bose 2002,63) has helped to transfer political legitimacy from the level of the individual or citizenry as a whole to a reified ethnic level (Mujkic 2007, 112-115), and has led to frequent institutional deadlock (Sebastián 2010, 323). It belies the notion of an integrated and united political structure, by giving power to sub-groups of elected representatives, based on their ethnic affiliation. The consociational constitution agreed at the DPA, by accepting the existence of three distinct ethnic groups seen as prosecuting the war, has therefore 
contributed to the reification of ethnic identities (Cooley 2013,193) and the institutionalisation of ethno-national division in the political and territorial structures of $\mathrm{BiH}$, producing the conditions over the last twenty years in which ethno-nationalist parties have been able to maintain their positions of dominance despite endemic failures in their governance.

The constructivist conflict framing, which viewed ethnic identity in $\mathrm{BiH}$ as contingent and potentially variable, informed post-war attempts at conflict transformation aimed at forging new and more cooperative identities in $\mathrm{BiH}$ (Cooley 2013, 175-176). The effects of this transformationalist approach can be seen most clearly in the major post-war endeavour which sought to mitigate and reverse the effects of ethnic cleansing: the policy of refugee return. This policy, which viewed ethnic cleansing as a violent attempt to create ethnically-pure territories from the patchwork of inter-mingled groups that existed before hostilities began, was first affirmed as a principle of the peace negotiations in the meeting of the International Conference on the Former Yugoslavia (ICFY) held in August 1992, and later found expression in the Washington Agreement of 1994, which created FBiH (Toal and Dahlman 2011, 148, 156), and, ultimately, in the text of the DPA. Annex 7 of the DPA declares that persons may return to their 'homes of origin' (Office of the High Representative 1995b), and repossess any property they inhabited before the war, with compensation being provided where this is not possible. This issue was seen as a hugely important matter, justifying the instigation of a wideranging international apparatus geared towards making it a political reality. For the then US Secretary of State Warren Christopher, the inclusion of Annex 7 was one of the reasons why the DPA could be considered 'a victory for all those who believe in multi-ethnic democracy' (Toal and Dahlman 2011, 161), as it attempted to overcome the homogenising effects of ethnic cleansing and recreate a pre-war BiH seen as a place of relative inter-ethnic harmony. Despite recognition amongst international officials that this could never completely reverse the demographic effects of ethnic cleansing by recreating the pre-1991 situation, the efforts have succeeded in returning over one million refugees and displaced persons to their former homes (Toal and Dahlman 2011, 286).

\section{Supplementing Dayton: The 'Balkans' war discourse}

How was it possible for the DPA to put into practice institutional arrangements and major policy endeavours inspired by contradictory understandings of the war in BiH? I will now look to the wider context within which the conflict was analysed and conceptualised by international actors, to illustrate the manner in which this contradiction was fixed by a reliance on an understanding of the 'Balkans' as a specific political space, where history and identity tend to play out in violent ways. To do so, I will first introduce the Derridean concepts of undecidability and the supplement, before arguing that an understanding of the conflict as a 'Balkans' war operates as the necessary supplement which gives the DPA a coherence which allows it to function as the basis of the political system in $\mathrm{BiH}$, while at the same time revealing the fault-lines within the DPA that are open to deconstruction.

\section{Derrida, undecidability and the supplement}

A variety of International Relations scholars have applied the work of Jacques Derrida to issues such as memory (Pinkerton 2012), resistance (Hirst 2015) and foreign policy (Bulley 2009), and to deconstruct the writings of theorists such as Michael Walzer (O'Callaghan 2013) and Hedley Bull (Edkins and Zehfuss 2005). Aspects of his thought have also been applied to the Bosnian war, most notably by Campbell (1998), who uses Derridean terms such as ontopology and différance to discuss 
the fixing of identity through territorial representation and argue for a radical form of multiculturalism as a response to the war. Derrida's work and key concepts are therefore fairly wellknown in the discipline, so I will not engage in a detailed exegesis of the manners in which he sought to unsettle the binary oppositions (such as masculine/feminine, reason/passion and civilised/barbarian) that structure Western thought through a 'metaphysics of presence'. I will, however, spend some time underlining the key Derridean concepts of undecidability and the supplement, which I will employ in my deconstruction of the DPA.

As Derrida stresses in his writings, the aim of deconstruction is not simply to invert the violent hierarchies which are central to Western thought but to 'mark the interval' between the overturning of these hierarchies and the creation of a new 'concept' that cannot be included in the binary system (Derrida 2005, 39). While the creation of a 'concept' outside of all previous structures of thought is impossible (Bulley 2009, 305), it is possible to develop marks which inhabit the space between the old regime and an impossible new one. These are the 'undecidables' that a deconstructive reading seeks to reveal within a text ${ }^{2}$, that 'can no longer be included within philosophical (binary) opposition, but which, however, inhabit philosophical opposition, resisting and disorganising it, without ever constituting a third term' (Derrida 2005, 40, italics in original).

One such undecidable that is central to Derridean thought is the 'supplement'. This was first introduced by Derrida in Of Grammatology $(1976,144-145)$, where he elaborates on its dual meaning in relation to the binary of speech/writing. Derrida discusses how speech has been granted a privileged position in Western metaphysics due to its assumed proximity to the actual 'presence' of thought, while writing is seen as a mere supplement to speech, that which is needed to transmit speech beyond its immediate environs. The supplement of writing is therefore that which is added to speech, a surplus that provides additional presence. However, this is only one way in which Derrida understands the supplement of writing: he also argues that writing acts as a substitute for speech, that which 'adds only to replace' speech, that which fills 'as if one fills a void'. This does not mean that writing is closer to the presence of thought than speech is, but that neither embodies the 'full presence' of thought, as this is seen by Derrida as a construction of Western metaphysics.

For Derrida these two understandings of the supplement cannot be separated, meaning that the supplement is both that which fulfils the presence of a prior concept and replaces this presence. It is therefore an undecidable in the sense that it cannot be reduced to either an addition or a replacement, but is both, simultaneously. Derrida argues that signifiers always require supplementation of this kind, to add 'more' presence, to extend the presence of the concept, but in a way that shows the concept to be empty (as if it was not empty it would not require the supplementation). Signifiers do not refer back to some mystical presence or wholeness, therefore, but only to other signifiers, stretching back in an endless 'chain of supplements' that 'produce the sense of the very thing they defer: the mirage of the thing itself, of immediate presence, of originary perception' (Derrida 1976, 145). I will now argue that an understanding of the Bosnian war as a typical 'Balkans' war operates as the necessary supplement which adds additional weight to the signifier of 'Dayton', while simultaneously operating as an undecidable that reveals the lack of presence within Dayton, acting as a fault-line within the DPA open to deconstruction. 
As Maria Todorova $(1997,136)$ has argued, 'the persistent use of "Balkan" for the Yugoslav war... rekindled old stereotypes and licensed indiscriminate generalizations about the region'. She shows how, beginning with its usage as a purely geographical moniker from the $15^{\text {th }}$ Century, the spatial and connotational significations of the term 'Balkan' have multiplied. Todorova (22) notes how 'Balkans' became a Romantic term, favoured by the poets and travel writers whose literary works ensured the term became synonymous with notions of 'ancient lands' seeped in history. This linking of the term with ideas of antiquity and the past intertwined with Enlightenment ideals of progress and teleology to feed-into the dichotomous thinking regarding 'East-and-West', whereby those in Western Europe see themselves as more politically and culturally advanced than their backward Eastern neighbours (Hansen 2006, 102-104). The Balkans was seen as separate from Europe due to its historical incorporation into the Ottoman Empire, a situation which persevered in parts of the region until the end of the First World War, while the communist nature of Tito's post-Second World War regime also separated the Socialist Federal Republic of Yugoslavia (SFRY) from capitalist Western Europe. Dichotomies of West-East were thus over-laid with those of European-Ottoman, capitalist-communist, and democracy-dictatorship to create a 'symbolic geography of eastern inferiority' (Bakić-Hayden and Hayden 1992, 3-4), with the Balkans relegated to the 'other' of Europe 'proper' (Coles 2007, 258-259).

These long-standing ideas of Balkan backwardness and otherness were over-laid with notions of conflict and violence in the early twentieth century, with the Balkan Wars and assassination of Archduke Franz Ferdinand in Sarajevo tying the term 'Balkan' to ideas of negativity, danger and menace. Todorova (1997, 33-34) notes how the term 'Balkanisation' was first used after the First World War to designate disintegration, conflict and internecine strife. Over the next eighty years, 'Balkans' and 'Balkanisation' became international stereotypes, bywords for anarchy and violence. This designator therefore provided a ready-made frame for international mediators when war broke out in $\mathrm{BiH}$ in 1992, allowing them to see the violence as part of an irresolvable conflict arising from ancient hatreds, or, in the words of Silber and Little $(1996,159)$, 'some ill-defined, but frequently alluded to, Balkan temperament, a south Slavic predisposition - either cultural or genetic - to fratricide'. This was a view prevalent on both sides of the Atlantic. The British Foreign Minister Douglas Hurd (1992) downplayed the possibility of successful intervention when he stated the August 1992 meeting of the ICFY that '[a]ncient hatreds are not easily soothed by outsiders', while President George H.W. Bush (1992) simply affirmed that '[b]lood feuds are very difficult to resolve'.

I will now show how this understanding of the Bosnian conflict as a typically 'Balkans' war, with its causes located in the deep past of the region, operates as a supplement to the war-time conceptualisations of the international actors discussed above. I will first take each of the framings in turn, before considering how the supplement of the 'Balkans' war understanding operates to smooth over the contradictions between the two war-time understandings, allowing them to operate together through the DPA.

\section{The 'Balkans' as supplement}

The 'Balkans' discourse clearly operates as a supplement to the 'ethnic war' understanding in the first sense of the word, adding additional weight to the argument that primordial chains of belonging drove ethnic agency in BiH. However, a supplementation in the second sense can also be identified, 
as the stress on the Balkans as a historically violent region worked to supplant the focus on ethnic identity as something spatially grounded in territory with an understanding of ethnic identity as temporally fixed and unchanging (Hansen 2016, 105). This supplementation made the creation of an ethnically-divided $\mathrm{BiH}$ appear to be the best solution to the conflict, as the specific understanding of ethnic identity that this understanding produced ensured that the only peace deal that was seen as enforceable was one based on ethnically-pure units and sustainable and secure territorial divisions (Silber and Little 1997, 350, 378).

In terms of the more constructivist conceptualisation of the conflict, and the policy of refugee return that it informed, a dependence on a supplementation by an understanding of the Balkans as a specific space where history and identity are intimately connected can be identified when we focus on the type of past that the policy of returns aimed to recreate. The right to return was given additional impetus as a policy through reference to the 1991 census data for $\mathrm{BiH}$, which showed a greater degree of inter-mixing and ethnic heterogeneity than was present immediately after the war $^{3}$. The right to vote in pre-war places of residence was also determined by location on the census roll, in a related policy which sought to mitigate the electoral effects of ethnic cleansing (Office of the High Representative 1995a). This may seem a reasonable mechanism for returning $\mathrm{BiH}$ to its prewar state, but asserting that census data could provide an accurate snapshot of the distribution of ethnicities in $\mathrm{BiH}$ at a particular time is itself dependent upon an understanding of ethnic identity as knowable, as existing 'within' communities and individuals, in a manner which obscures any understandings of the 'inventive', simplifying and homogenising effects of census-taking (Anderson 1991).

The 'Balkans' supplement which sees ethnic identity as immutable in BiH can be seen at work here, adding weight to the idea that ethnic distributions before the war can be calculated and recreated in the present. History is again the reference point: not a history of 'ancient hatreds', but the pre-war history of ethnic identity in the SFRY, formalised through mechanisms like the census and concepts such as the 'constituent peoples' created by the 1971 constitutional amendments (Toal and Dahlman 2011, 4) and the 'ethnic keys' used to distribute certain positions according to ethnic proportion in the various Yugoslav republics (Gagnon Jr. 1994/95, 141). A different historical reference is being made, and a different idea of ethnic identity is being essentialised (one that is capable of inter-mixing and living in relative harmony, rather than one predetermined to conflict), but the implication that ethnic identity is consistent over time is still present, driving the policy of remaking an ethnic mix that was destroyed by the war.

The supplementation therefore works here to supplant and replace the constructivist understanding of ethnic identity as fluid and changeable that seems at first glance to inform refugee return, meaning that the policy in fact depends upon similar assumptions regarding ethnicity as unchanging and territorially-bounded as those that inform the 'ethnic war' understanding. As Campbell (1998, 79) has argued, the use of the 1991 census statistics as a tool in the re-engineering of the pre-war ethnic mix acts to establish the markers of identity constructed through the census 'as socially salient, the community fault lines around which politics will revolve'. The ethnic mix identified by the census, in the very year that conflict first erupted, is thus treated as a fixed and unchanging reality, the rigid backdrop against which the war played out. The focus of the returns policy on reversing the displacement of members of an ethnic group from a specific territory implies that identity is rooted in the place from which one originates (Stepputat 1994, 176). While this is no doubt important, and 
must not be casually dismissed, factors such as social interactions and inter-cutting networks of belonging beyond the immediate locale are also important. The efforts to return the displaced to their 'home' thus builds upon the very conception of the possibility of distinct homelands for distinct groups that resulted in the displacement in the first instance (Black 2002, 126). It accepts the idea that ethnic groups in the Balkans 'belong' in a specific territorial environment, and thus is itself dependent on a fixed understanding of ethnic identity in $\mathrm{BiH}$.

The contradictory understandings of the conflict as an ethnically-motivated civil war and an elitedriven enterprise which manipulated ethnic signifiers are therefore held together in the DPA through reference to the wider 'Balkans' context within which the war was seen to play out. The primordialist and constructivist conceptions of agency in $\mathrm{BiH}$ are both connected through a chain of supplementation to the 'Balkans' understanding of the conflict, resulting in the privileging of historically-fixed and territorially-bounded understandings of ethnic identity. The consequences of this supplementation is apparent in the manner in which the implementation of Annex 7, when left in the hands of local ethno-nationalist parties, has been utilised as another means of consolidating ethnic control over specific pieces of territory. Bosniak Party for Democratic Action politicians have talked of the returns process allowing them to 'retake' territory that had been lost during the war, while the same party opposed minority returns in other areas with Bosniak majorities. Tuđman and Croatian Democratic Union hardliners pursued a strategy of using financial support to concentrate Croat returnees in western Herzegovina, at the expense of facilitating their return to RS or Bosniakmajority areas, in order to strengthen the Croat character of this stretch of land, while the Serbian Democratic Party employed similar tactics to solidify their control over southern Brčko, with 25,000 displaced Serbs from FBiH assigned to apartments in that area (Toal and Dahlman 2011, 176-216). These cases illustrate how the institutional- and territorial-divisions of $\mathrm{BiH}$ and the policy of returns are informed by a singular ethnic logic, grounded in the 'Balkans' understanding of the conflict, allowing them to be wielded as mutually-reinforcing instruments for consolidation of territory by ethno-nationalist parties.

The DPA not only depends upon an understanding of the war as a 'Balkans' war but, through the understanding of ethnic identity which informs both the institutional divisions and the policy of return, it transmits the logic of the 'Balkans' war, the logic of fixed identities and inter-ethnic competition, into the present politics of $\mathrm{BiH}$, in a manner which obscures other articulations of identity in BiH. The DPA can thus be said to enact a 'Balkanisation' of politics in $\mathrm{BiH}$, by providing the mechanisms through which the dominant ethno-nationalist parties are able to continue to advance the war-time strategies of the ethnic control over territory through political means. The supplement of the 'Balkans' war is carried into the contemporary political environment through the DPA, structuring it around a conception of ethnic and territorial difference as immutable and unchanging. Identifying this process, whereby the DPA seeks a completeness that it lacks through supplementation, directs us towards the points at which the DPA 'is already in the process of falling apart because of its internal contradictions' (Bulley 2009, 306). The traces of the 'Balkans' war discourse contained within the DPA are therefore both essential to holding the text together, to allowing it to function as the basis of a political system, while simultaneously operating as the weakpoints where the DPA can be shown to deconstruct under its own logic.

How can such a deconstruction be enacted in practice? Through an engagement with recent protest movements in $\mathrm{BiH}$, I will suggest how a deconstruction of the DPA can be enacted as a political 
strategy to challenge both the fixed understanding of ethnic identity built into the DPA and the fixed ethnic understanding of the war that these are based upon. Such a process of deconstruction, I will argue, can perhaps allow Bosnian politics to develop on a trajectory distinct from that mapped out by the war-time strategies of the extreme nationalists.

\section{Deconstruction and Political Protest in BiH}

We are hungry in more than one language

In February 2014 street protests which began in Tuzla, the former industrial city where thousands of employees had been made redundant from their once-productive factories, spread to all the major cities of BiH (including the de facto capital of RS, Banja Luka). While these events captured the attention of the international media, largely due to the violent emanations of the protests (fires were started in cantonal government offices in Tuzla, Mostar and Sarajevo, and in the state archives and the presidency building in the capital), they can be seen as the latest stage in a series of protest movements that have emerged in $\mathrm{BiH}$ in recent years. In 2012 numerous protests had attempted to prevent the closure of the National Museum in Sarajevo, and campaigns to protect the status of other cultural institutions, such as the National Art Gallery, the National and University Library and the National Film Archive, are ongoing. The summer of 2013 also saw widespread protests over the death of the three month old Berina Hamidovic, who was unable to travel to Serbia for medical treatment due to a dispute over the issuing of identity cards (Dedovic 2013).

In February 2014 the protests developed into a political forum, with 'plenums' or councils being set up in the major cities, attempting to build on the earlier protests and social movements to articulate a new style of radically-democratic politics, consciously avoiding relations with political parties, nongovernmental organisations and the myriad international agencies operating in BiH (McRobie 2014) that were held culpable for the political stagnation and gridlock that has paralysed the country and stunted its development. Despite early enthusiasm, these plenums failed to develop into a political movement that could challenge the electoral dominance of the ethno-nationalist parties. By engaging in a Derridean reading of the slogan 'we are hungry in three languages', which was widely circulated and deployed during the protests, I will now argue that this failure can be attributed to the fact that protests targeted the current ethnic divisions in $\mathrm{BiH}$ without challenging the source of this division in the ethnic understanding of the war. Overcoming the fixed ethnic basis of politics in $\mathrm{BiH}$ requires completing the deconstructive gesture by deconstructing the supplement of the 'Balkans' war which enables the continuing ethnicisation of BiH enacted through the DPA.

'We are hungry in three languages' was displayed on banners at various protest sites in BiH. Images containing this slogan, which refers to the three de facto official 'languages' of BiH (Bosnian, Croatian and Serbian, each claimed by a different ethno-national group $)^{4}$, were widely circulated on social media, and the phrase even found its way into the title of an article written by the former High Representative for BiH Wolfgang Petritsch $(2014)^{5}$. The slogan also echoes one of the few definitions Derrida (1989, 15, italics in original) ever proffered for deconstruction, when he wrote that if he 'had to risk a single definition of deconstruction, one as brief, elliptical, and economical as a password, I would say simply and without overstatement: plus d'une langue - both more than one language and no more of just one language'. Derrida admitted this 'definition' is neither a statement nor a sentence, but something that highlights the centrality to deconstruction of translation, of transference among and within languages (Derrida 1988, 1). In his playful style, it is a definition to be 
put into use, to be inserted into language and discourse as a destabilising gesture. What would it mean, then, to put this definition 'into use' in the context of the slogan referenced above?

A deconstructive reading can view the slogan 'we are hungry in three languages' as disrupting the division of $\mathrm{BiH}$ into three distinct ethno-linguistic groups by introducing an element of undecidability between them. The slogan is simultaneously saying 'we are hungry no matter what language we speak' and showing how the statement 'we are hungry' can be written once in 'all three languages', thus challenging the division of $\mathrm{BiH}$ on an ethno-linguistic basis. If this was merely a protest about living standards or a call to universal solidarity the banner need only have read 'We are hungry'. The playful and subversive addition of 'in three languages' (the text is only written once, not 'translated' into the other languages) makes it clear that no translation is needed between the 'three languages'. It is a slogan written in Bosnian, Croatian, Serbian and the now-defunct Serbo-Croat, all at once. It is any one of these languages, and all of them, and therefore cannot be appropriated solely by any one language. To say 'we are hungry in three languages' in Bosnian, in Croatian or in Serbian is an unstable, unsustainable statement. It would be a statement that reveals the fiction of that language's uniqueness, by making it clear that the slogan would be the same in any of the other languages. Even if rendered in the Cyrillic script in an attempt to fix its meaning in Serbian, the slogan would break free again when chanted at a protest march or read aloud by those who view it in person, on television or online. The slogan therefore reveals the emptiness of claims to the immanent reality of ethnic difference in $\mathrm{BiH}$ that rest upon that the assertion of linguistic difference.

\section{Deconstructing the supplement}

While this slogan offers an indication of how deconstruction has been employed by movements which seek to challenge the ethnic division of politics in $\mathrm{BiH}$, it cannot be the basis for a sustained engagement with the ethnic logic which permeates the DPA. This is because the slogan does not address the source of the ethnic division that it seeks to displace: in other words, it targets the effects of the supplementation of the DPA with the 'Balkans' understanding of war, without challenging the supplement itself. To do so, more is needed than a deconstruction of the contemporary iterations of ethnic division, no matter how much they are seen as the cause of current hardship and alienation by those engaging in protest. Rather, a deconstruction which challenges both the present ethnic divisions and their basis in historical conceptualisations must be enacted: a deconstruction which radiates its effects both backwards and forwards in time.

I argued in the second section that the supplementation of the DPA enacts a 'Balkanisation' of politics in $\mathrm{BiH}$, in the sense of transmitting the war-time logic of violent and historically-determined ethnicity into the present political situation. This ethnicising logic is what is targeted by the slogan discussed above, which deconstructs the claims that the Bosnian population are naturally divisible into three distinct ethno-linguistic groups, and that political arrangements should accommodate this 'fact'. What the slogan fails to do, however, is show how the supplement itself can be deconstructed, not just its effects in the present. The supplementation of the DPA by a 'Balkans' framing of the conflict is a mutually-constitutive process which (re)enacts an understanding of the conflict as a 'Balkans' war through the continuing application of the DPA. The supplement is thus not 'prior' to that which it supplements: rather, the very process of supplementation gives presence to both the DPA and the 'Balkans' discourse in the same temporal instant. As Derrida $(1982,13)$ has stated, the production of meaning through supplementation 
is possible only if each so-called 'present' element, each element appearing on the scene of presence, is related to something other than itself, thereby keeping within itself the mark of the past element, and already letting itself be vitiated by the mark of its relation to the future element.

The 'present' is, according to Derrida, given presence by dividing from itself a past-as-presence and a future-as-presence, thus constituting the linear temporality that structures everyday action and thought. Just as deconstruction can be used to reveal the inherent instability of the hierarchical relations between the binary opposites which structure linguistic and philosophical systems, so can it be used to target our linear temporal assumptions. Derrida (1995, 30-31, italics added) offers one potential means for enacting such a temporal deconstruction when he states in 'The time is out of joint' that the 'teleological schema can be applied to everything' except 'to that which in it begins by questioning, displacing, and dislocating the machine of this teleology'. In other words, to oppose or overturn systems of thought or action which derive legitimacy from a conception of a beginning, we must begin with a questioning of this beginning, and of the very concept of 'the beginning' as such. This form of critique must inhabit the beginning, displace the attempt to derive legitimacy from a conception of beginning, and refute the search for authority in a beginning.

To deconstruct the DPA, we must therefore begin by deconstructing the 'Balkans' supplement that gives presence to the fixed understanding of ethnic identity in $\mathrm{BiH}$ found within it. This can be enacted in the present through highlighting the competing understandings of the causes of the conflict that are displaced by the 'Balkans' war discourse. The conflict can be seen as resulting from the collapse of communism as a rival for economic liberalism and the effects this had on stability in the former socialist states (Woodward 1995); the dynamics of a societal security dilemma (Posen 1993); or the strategic policies 'chosen by elites who were confronted with political pluralism and popular mobilization' (Gagnon Jr. 2004, 7). Rather than replacing the 'Balkans' war understanding with one of its rivals, a deconstructive approach would highlight the lack of consensus around what caused the conflict, and thus criticise the DPA not on the grounds that it embodies the incorrect explanation of the war (as this implies there is a correct explanation), but because it fixes one particular understanding through the institutions it puts into place.

While the 'Balkans' understanding of the war remains the guiding principle of the DPA, no attempt at reform will deliver a political system freed from the dominance of ethno-nationalist parties. It is for this reason that an opening up of historic understandings of the conflict must be undertaken. If it were necessary to distil such a political project into an addition to the slogan discussed above perhaps the wording could be: 'The war made us speak three languages; now we are hungry in three languages'. Such a slogan makes it clear that without the war there would not be 'three languages', there would not be a political division based on three different languages, a division demanding territorial and institutional arrangements designed to protect one group from the ethnic 'others' and engendering political and economic stagnation. The second part of the slogan then displaces that ethnic division, revealing the fiction of the neat division of Bosnians into three distinct and opposed groups based on a constructed ethno-linguistic difference. Taken together, the two parts to the slogan target both the conceptualisation of the war as being fought between separate ethnic groups, and the continuing negative effects of that conceptualisation on contemporary politics in $\mathrm{BiH}$. 
Such a slogan would not replace the hard political work of attempting to challenge the ethnic divisions permeating Bosnian politics, but it (or something like it) can provide an indication of what such a political strategy might look like: a politics that does not seek to transcend the political framework constructed through the DPA, as the plenums attempted to do, but one which challenges the fixed understanding of the war that the DPA is based upon while transmitting these into the present, and the essentialisation of ethnic identity that this enacts. Targeting both the ethnicising consequences of the DPA and the ethnic understanding of the war that informs the DPA must be the dual goal of any statebuilding project that seeks to overcome the ethnicisation of politics in post-war

$\mathrm{BiH}$. The foundational principles of the institutionally- and territorially-divided state are currently the content of polarising debate between the rival ethno-nationalist parties (Toal and Dahlman 2011, 310). Such debate over the DPA must not be left to the ethno-nationalists: rather, if the deadlock and dysfunction that characterise contemporary politics in $\mathrm{BiH}$ is to be overcome, the DPA must be made the target of an affirmative deconstruction that seeks to overturn and move beyond the fixed conceptions of ethnic identity embedded within it.

\section{(Against) Conclusions}

This article has argued for a conclusion of the Dayton structures, but not a conclusion as normally understood. Conclusions usually provide a juncture within a linear temporal schema, an ending that also signals a new beginning, as time continues its inexorable onwards march. A conclusion, however, can do more than this, can perform more than such a Janus-faced looking-forwards and looking-backwards in a manner which reinforces dominant understandings of time as the linear progression from past-to-present-to-future. A conclusion can aspire to disrupt and unsettle these norms, do more than just mark an ending and simultaneously signal a new beginning - it can upset settled notions of linearity, alter how ending and beginning are conceived, push time backwards, allow the whole to be expressed in one temporal instant.

Following Derrida, this could be called a 'deconstructive conclusion'. Deconstruction targets all ideas of presence, meaning that for Derrida the present is characterised as much by absence as by presence. It is co-constituted by an absent past and an absent future, producing a present crisscrossed with ghosts of the past and the unknowns of the future 'to come' ${ }^{6}$. Any attempt to say a last word on the past, or to intimate towards new lines of thought for the future, are therefore impossible to maintain. They are prey to deconstructive movements, which can reveal how the past remains lodged in all attempts to move on from it, and how the unknowable horizon of the future structures all attempts to think the past or present. A deconstructive conclusion can be conceived 'like a door on its hinges', like time 'folding back on itself' (Derrida 1995, 14, italics in original) as it radiates its effects backwards and forwards in time, unsettling linear conceptions of temporality by revealing how all moments in time, including the moment of conclusion, are marked by traces from the past and looking forwards to the future.

A deconstructive conclusion of the DPA would show how the political present in BiH is built around an absence that requires supplementation by a discourse which sees the past in terms of a 'Balkans' war; and that this past is itself marked by absence, by the absence of any certainty that the war was the ethnically-determined 'Balkans' war that the DPA depends upon, or that the 'Balkans' is a more violent region than other parts of the world (Malešević 2012). The 'end' of the ethnically-divided political system therefore requires the end of the ethno-political framework constituted through the 
DPA, which enacted and sustained it. The end must undo the beginning. More than this, the end of the DPA must bend time backwards, in the sense of allowing the war to be conceived in different manners. For if the war can be understood as something other than the inevitable clash of fixed ethnic identities, a political system designed to keep these ethnic groups from resuming violence will not be such a necessity. The effects of the 'conclusion' of the Dayton system must therefore radiate back to the time before its beginnings, to the years of international engagement during the war, to how the war is understood and to how the term 'Balkan' is understood. This can be both in a narrowly political sense and through wider social or cultural processes encompassing artefacts and productions such as history textbooks ${ }^{7}$, memorials and art works.

Yet the effects of such a deconstructive conclusion are not limited to one direction on a linear temporal schema: the deconstruction works both ways. As well as showing how the DPA is dependent upon an ethnic understanding of the war, a deconstructive conclusion must show how the ethnic understanding of the war is given presence in the present through the Dayton political structures. Challenging and overcoming these political structures in the present can therefore allow different understandings of the war to develop. Such an unsettling of linear temporality is central to the deconstructive conclusion that can bring an end to the ethnic divisions enacted through the DPA. Overcoming the blockages which prevent BiH from moving forward will not be achieved through new constitutional agreements made in the present, or through new political constellations which marginalise the nationalist parties and international agencies, but through a reappraisal of the past, a reconfiguration of the past that can undo this aporia and allow the present and future to be reconfigured too. This is not to deny the impacts that the war continues to have on people's lives in $\mathrm{BiH}$, or the continuing salience of ethnic markers of identity to many people. It is not enough to simply re-interpret the war in a non-ethnic manner and wait for new, less oppositional identities and belongings to emerge. A deconstructive conclusion of the DPA would not be achieved in one temporal moment: rather, it would be a process, an engagement with understandings of the war alongside an engagement with current political arrangements, informed by a recognition that the fixed understanding of the war and the current manifestations of essentialised ethnic difference in the political system are rooted in each other and must therefore be challenged together.

It is now over twenty years since the end of the Bosnian war, but the need to deconstruct the conclusion of that war, to deconstruct the DPA, is as pressing as ever. The same could be said of other long-term peace processes, such as the one in Northern Ireland which has largely succeeded in removing violence from the political arena but at the expense of institutionalised division and frequent impasses over issues such as how to deal with the historical legacy of violence. In the case of wars that are currently ongoing or in unstable ceasefire, such as those in Syria and the Ukraine, the need to bring about a halt to the bloodshed or ensure a more enduring peace may require an end to the conflict such as that negotiated at Dayton: an end which does not exhaust the logics of division which enabled the violence, but transmits them into the present. This may truly be the best option when conflicts reach the ignominious depths touched in $\mathrm{BiH}$ in 1995 and in Syria at present, when the ethos of the deconstructive conclusion developed in this article would have little policyrelevance for those attempting to negotiate peace. Compromise and pragmatism may have great utility in producing interim agreements that allow for transitions from war to peace (Vrbetic 2013), but these must not be allowed, as the DPA has in $\mathrm{BiH}$, to become the 'eternal blueprint for the structure of the country' (Perry 2016, 35). While the true measure of the wider merit of this approach must await the test of future scholarship, a deconstructive conclusion, an active process of 
engagement with the fixed understandings that often inform conflicts as well as conflict resolutions, can perhaps allow for peace processes to develop which do more than continue war by other means.

\section{Funding}

Part of the research for this article was conducted between 2007 and 2010 for my PhD, which was funded by an ESRC +3 studentship.

\section{Acknowledgements}

I would like to thank Cristina Masters, Laura McLeod, Aggie Hirst and Gemma Collantes-Celador for their helpful advice on an earlier version of this article, Bronagh Kealey for her diligent proof-reading of a final draft, and the two anonymous reviewers for their constructive and insightful comments.

\section{Author Biography}

Patrick Pinkerton is a Visiting Lecturer in International Politics at City University London. He has previously published work on the politics of memorialisation in post-conflict Northern Ireland in the British Journal of Politics and International Relations.

\footnotetext{
Notes

${ }^{1}$ I use the term 'ethno-nationalist' to capture both the claims to linguistic and religious difference and to a degree of political and territorial self-determination.

${ }^{2}$ It is important to make clear that for Derrida a 'text' is everything that is open to interpretation, not just written material. The DPA is therefore open to deconstruction, both as it is a written document and due to the conceptualisations embedded within it which must be engaged with interpretatively.

${ }^{3}$ A new census was held in 2013, though it has yet to be published. See Bieber (2015b) for more on the BiH census in a post-Yugoslav context.

${ }^{4}$ While the Dayton constitution does not specify the 'official languages' of BiH, Article 11 of the DPA gives de facto recognition to the three languages by stating the text is written in 'the Bosnian, Croatian, English and Serbian languages, each text being equally authentic' (Office of the High Representative 1995c).

${ }^{5}$ Petritsch acted as High Representative between August 1999 and May 2002.

${ }^{6}$ See Derrida (1996) for more on this idea.

${ }^{7}$ See Levy $(2014,76-77)$ for a discussion of the role of the DPA in the development of a divided education system in $\mathrm{BiH}$.
}

\section{References}

Anderson, Benedict. 1991. Imagined Communities: Reflections on the Origin and Spread of Nationalism (Revised Edition). London: Verso, 1991.

Bakić-Hayden, Milica and Robert M. Hayden. 1992. "Orientalist Variations on the Theme 'Balkans': Symbolic Geography in Recent Yugoslav Cultural Politics." Slavic Review 51 (1): 1-15.

Bieber, Florian. 2015a. "Bosnia and Herzegovina: A Failed Success." In State-Building and Democratization in Bosnia and Herzegovina, edited by Soeren Keil and Valery Perry, 213219. Farnham: Ashgate Publishing Limited. 
Bieber, Florian. 2015b. "The Construction of National Identity and its Challenges in Post-Yugoslav Censuses." Social Science Quarterly 96 (3): 873-903.

Black, Richard. 2002. "Conceptions of 'Home' and the Political Geography of Refugee Repatriation: Between Assumptions and Contested Reality in Bosnia-Herzegovina." Applied Geography 22 (2): 123-138.

Bose, Sumatra. 2002. Bosnia After Dayton: Nationalist Partition and International Intervention. London: Hurst and Company.

Bulley, Dan. 2009. "Textualising British Politics: Deconstructing the Subject of British Foreign Policy." British Politics 4 (3): 291-314.

Bush, George H.W. 1992. "Containing the Crisis in Bosnia and the Former Yugoslavia." US State Department Dispatch, 10 August. Accessed July 29, 2015. http://dosfan.lib.uic.edu/ERC/briefing/dispatch/1992/html/Dispatchv3Sup7.html

Campbell, David. 1998. National Deconstruction: Violence, Identity, and Justice in Bosnia. Minneapolis, MN: University of Minnesota Press.

Chandler, David. 2000. Bosnia: Faking Democracy after Dayton (Second Edition). London: Pluto Press.

Coles, Kimberley. 2007. "Ambivalent Builders: Europeanization, the Production of Difference, and Internationals in Bosnia-Herzegovina." In The New Bosnian Mosaic: Identities, Memories and Moral Claims in a Post-War Society, edited by Xavier Bougarel, Elissa Helms and Ger Duijzings, 255-272. Aldershot: Ashgate Publishing Limited.

Cooley, Laurence. 2013. "The European Union's Approach to Conflict Resolution: Insights from the Constitutional Reform Process in Bosnia and Herzegovina." Comparative European Politics 11 (2): 172-200.

Dedovic, Edin. 2013. "Bosnia's Baby Revolution: Is the Protest Movement Coming of Age?" Open Democracy, 26 June. Accessed March 10, 2016. https://www.opendemocracy.net/edindedovic/bosnia\%E2\%80\%99s-baby-revolution-is-protest-movement-coming-of-age

Derrida, Jacques. 1976. Of Grammatology. Translated by Gayatri Chakravorty Spivak. Baltimore, MD: The John Hopkins University Press.

Derrida, Jacques. 1982. Margins of Philosophy. Translated by Alan Bass. Chicago, IL: University of Chicago Press.

Derrida, Jacques. 1988. "Letter to Japanese Friend." Translated by David Wood and Andrew Benjamin. In Derrida and Différance, edited by David Wood and Andrew Benjamin, 1-6. Evanston, IL: Northwestern University Press,

Derrida, Jacques. 1989. Memoires for Paul de Man. Translated by Peggy Kamuf. New York, NY: Columbia University Press.

Derrida, Jacques. 1995. "The Time is Out of Joint." Translated by Peggy Kamuf. In Deconstruction Is/In America: A New Sense of the Political, edited by Anselm Haverkamp, 14-38. New York, NY: New York University Press.

Derrida, Jacques. 1996. Archive Fever: A Freudian Impression. Translated by Eric Prenowitz. Chicago, IL: University of Chicago Press.

Derrida, Jacques. 2005. Positions (2nd edition). Translated by Alan Bass. London: Continuum.

Edkins, Jenny and Maja Zehfuss. 2005. "Generalising the International." Review of International Studies 31 (3): 451-472.

Efendić, Adnan and Azra Hadžiahmetović. 2016. "Post-War Economic Transition in Bosnia and Herzegovina - A Challenging Transformation." In State-Building and Democratization in Bosnia and Herzegovina, edited by Soeren Keil and Valery Perry, 109-129. Farnham: Ashgate Publishing Limited.

Eller, Jack David and Reed M. Coughlan. 1993. "The Poverty of Primordialism: The Demystification of Ethnic Attachments." Ethnic and Racial Studies 16 (2): pp. 183-202. 
Gagnon Jr., V.P. 1994/95. "Ethnic Nationalism and International Conflict: The Case of Serbia." International Security 19 (3): 130-166.

Gagnon Jr., V.P. 2004. The Myth of Ethnic War: Serbia and Croatia in the 1990s. London: Cornell University Press.

Hirst, Aggie. 2015. "Derrida and Political Resistance: The Radical Potential of Deconstruction." Globalizations 12 (1): 6-24.

Hansen, Lene. 2006. Security as Practice: Discourse Analysis and the Bosnian War. Abingdon: Routledge.

Howard, Lise Morjé. 2015. "US Foreign Policy Habits in Ethnic Conflict." International Studies Quarterly. Early View article. Accessed December 9, 2015. http://0onlinelibrary.wiley.com.wam.city.ac.uk/doi/10.1111/isqu.12213/abstract

Howard, Lise Morjé. 2012. "The Ethnocracy Trap." Journal of Democracy 23 (4): 155-169.

Hurd, Douglas. 1992. "Presidency Intervention." London Conference general debate, 26 August. Balkan Odyssey CD-ROM, Academic Edition v1.1. London: The Electric Company.

Inzko, Valentin. 2015. "Op-ed by the High Representative on the 20th Anniversary of the Dayton Peace Agreement." Overview Service, 28 June. Accessed March 10, 2016. http://www.sos.ba/e_inzko.html

Kappler, Stefanie. 2013. "Everyday Legitimacy in Post-Conflict Spaces: The Creation of Social Legitimacy in Bosnia-Herzegovina's Cultural Arenas." Journal of Intervention and Statebuilding 7 (1): 11-28.

Kaufmann, Chaim. 1996. "Possible and Impossible Solutions to Ethnic Civil Wars." International Security 20 (4): 136-175.

Levy, Naomi. 2014. "International Peacebuilding and the Politics of Identity: Lessons from Social Psychology Using the Bosnian Case." Journal of Intervention and Statebuilding 8 (1): 68-90.

McEvoy, Joanne. 2014. "The Role of External Actors in Incentivizing Post-Conflict Power-Sharing." Government and Opposition 49 (1): 47-69.

McRobie, Heather. 2014. "Listen to Bosnia's Plenums." Open Democracy, 25 March. Accessed March 10, 2016. https://www.opendemocracy.net/5050/heather-mcrobie/listen-to-bosniasplenums

Malešević, Siniša. 2012. "Did Wars Make Nation-States in the Balkans? Nationalisms, Wars and States in the 19th and Early 20th Century South East Europe." Journal of Historical Sociology 25 (3): 299-330.

Mujkic, Asim. 2007. "We, the Citizens of Ethnopolis." Constellations 14 (1): 112-128.

O'Callaghan, Ronan. 2013. "Secular Theology and Noble Sacrifice: The Ethics of Michael Walzer's Just War Theory." Review of International Studies 39 (2): 361-383.

Office of the High Representative. 1995a. "The General Framework Agreement: Annex 3." 14 December. Accessed March 10, 2016. http://www.ohr.int/?page_id=63253\&lang=en

Office of the High Representative. 1995b. "The General Framework Agreement: Annex 7." 14 December. Accessed March 10, 2016. http://www.ohr.int/?page_id=63261\&lang=en

Office of the High Representative.1995c. "The General Framework Agreement for Peace in Bosnia and Herzegovina." 14 December. Accessed July 27, 2015. http://www.ohr.int/dpa/default.asp?content_id=379

Perry, Valery. 2015. "Constitutional Reform Processes in Bosnia and Herzegovina: Top-down Failure, Bottom-up Potential, Continued Stalemate." In State-Building and Democratization in Bosnia and Herzegovina, edited by Soeren Keil and Valery Perry, 15-40. Farnham: Ashgate Publishing Limited.

Petritsch, Wolfgang. 2014. "Bosnians are Hungry in Three Languages: Bosnia Must Escape From its Dead End through Complete Reform of its Failed Political System - With the Aid of a New EU Marshall Plan." Balkan Insight, 19 February. Accessed March 10, 2016.

http://www.balkaninsight.com/en/article/bosnians-are-hungry-in-three-languages 
Pinkerton, Patrick. 2012. "Resisting Memory: The Politics of Memorialisation in Post-Conflict Northern Ireland." British Journal of Politics and International Relations 14 (1): 131-152.

Posen, Barry R. 1993. "The Security Dilemma and Ethnic Conflict." Survival 35 (1): 27-47.

Sebastián, Sofía. 2010. "Statebuilding in Divided Societies: The Reform of Dayton in Bosnia and Herzegovina." Journal of Intervention and Statebuilding 4 (3): 323-344.

Sebastián, Sofía. 2012. "Constitutional Engineering in Post-Dayton Bosnia and Herzegovina." International Peacekeeping 19 (5): 597-611.

Silber, Laura and Allan Little. 1996. The Death of Yugoslavia (Revised Edition). London: Penguin Books.

Stepputat, Finn. 1994. "Repatriation and the Politics of Space: The Case of the Mayan Diaspora and Return Movement." Journal of Refugee Studies 7 (2/3): 175-185.

Stravidis, James. 2015. "Syrian Ghosts: What the Balkans Can Teach us About How to End the Conflict in the Levant." Foreign Policy, 6 November. Accessed March 10, 2016. http://foreignpolicy.com/2015/11/06/lessons-from-the-balkans-for-

Syria/?utm_content=buffer8ab7b\&utm_medium=social\&utm_source=twitter.com\&utm_ca mpaign=buffer

Stroschein, Sherrill. 2014. "Consociational Settlements and Reconstruction: Bosnia in Comparative Perspective (1995-present)." Annals, The American Academy of Political and Social Science 656 (1): 97-115.

Toal, Gerard and Carl T. DahIman. 2011. Bosnia Remade: Ethnic Cleansing and its Reversal. Oxford: Oxford University Press.

Todorova, Maria. 1997. Imagining the Balkans. Oxford: Oxford University Press.

Vrbetic, Marta. 2013. “Afraid of a 'Kosovo Scenario': A Disquieting Precedent for International Conflict Management." Journal of Intervention and Statebuilding 7 (3): 308-334.

Woodward, Susan. 1995. Balkan Tragedy: Chaos and Dissolution after the Cold War. Washington D.C.: The Brookings Institute. 